\title{
Reconstruction of the pollution history of alkylphenols (4-tert-octylphenol, 4-nonylphenol) in the Baltic Sea
}

\author{
Bożena Graca $^{1} \cdot$ Marta Staniszewska $^{1} \cdot$ Danuta Zakrzewska $^{1} \cdot$ Tamara Zalewska $^{2}$
}

Received: 2 September 2015 / Accepted: 7 February 2016/Published online: 2 March 2016

(C) The Author(s) 2016. This article is published with open access at Springerlink.com

\begin{abstract}
This paper reports the reconstruction of the pollution history of 4-tert-octylphenol (OP) and 4-nonylphenol (NP) in the Baltic Sea. Alkylphenols are endocrinedisrupting compound and therefore toxic to aquatic organisms. Sediment cores were collected from regions with relatively stable sedimentation conditions. The cores were dated by the ${ }^{210} \mathrm{~Pb}$ method. The OP and NP were determined using HPLC-FL. The highest inventory of these compounds was observed in the Gotland Deep $\left(610 \mu \mathrm{g} \mathrm{m} \mathrm{m}^{2}\right.$ of NP and $47 \mu \mathrm{g} \mathrm{m}^{2}$ of OP) and the lowest-on the slope of the

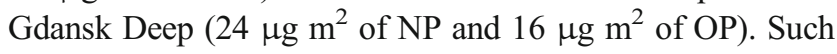

Responsible editor: Roland Kallenborn

\section{Highlights}

1. Pollution history of alkylphenols in the Baltic Sea has been reconstructed

2. OP and NP pollution trends coincide with the beginning of eutrophication

3. OP and NP pollution trends coincide with increasing $\mathrm{O}_{2}$ deficit during the twenty-first century

4. Spatial distribution of OP and NP is probably influenced by the uplift of the sea floor

Electronic supplementary material The online version of this article (doi:10.1007/s11356-016-6262-8) contains supplementary material, which is available to authorized users.

Marta Staniszewska

marta.staniszewska@ug.edu.pl

1 Department of Marine Chemistry and Environmental Protection, Institute of Oceanography, University of Gdansk, Al. Marszałka Piłsudskiego 46, 81-378 Gdynia, Poland

2 Institute of Meteorology and Water Management, National Research Institute, Maritime Branch, Waszyngtona Str. 42, 81-342 Gdynia, Poland spatial distribution was probably, among other factors, the result of the uplift of the sea floor. The pollution trends of OP and NP in sediments coincided with the following: (1) the beginnings of eutrophication (1960s/1970s of the twentieth century) and (2) strong increase in the areal extent and volume of hypoxia and anoxia in the Baltic (present century).

Keywords Alkylphenols · 4-nonylphenol ·

4-tert-octylphenol $\cdot$ Sediment cores $\cdot$ Pollution reconstruction $\cdot$ Baltic

\section{Introduction}

Since the 1980s of the last century, 4-tert-octylphenol (OP) and 4-nonylphenol (NP) have been of environmental concern because of their toxicity for aquatic organisms (McLeese et al. 1981; Comber et al. 1993), estrogenic properties (Soto et al. 1991; Jobling and Sumpter 1993; Jobling et al. 1996) and widespread contamination. NP and OP belong to the broader group of compounds known as alkylphenols. They have been used for decades (Fiege et al. 2000) and the list of their applications is very long (COHIBA 2011a, b; OSPAR 2009; HELCOM 2009; 2010). The NP is mainly used for the synthesis of alkylphenol ethoxylates (NPEs). This compound belongs to the world's third largest group of surfactants with various industrial, institutional and household applications. The OP is also used in the synthesis of alkylphenol ethoxylates (OPEs). However, its main application is the production of phenolic resin, predominantly as a tackifier in the vulcanization process for the manufacture of rubber tires. Generally, the OP, NP, and their ethoxylates are used in the following: textile industry, production of plastics, water-based 
paints, herbicides, pharmaceuticals, cosmetics and washing agents, as well as in pulp and paper processing and steel manufacturing (COHIBA 2011a, b; Jahan et al. 2008). Such extensive use causes NP and OP as widespread contaminants in natural environment. The main sources of OP and NP and their parent compounds, alkylphenol polyethoxylates (Ahel et al. 1994a; 1994b; Ying et al. 2002) for the marine environment are municipal and industrial wastes. Some of the authors pointed the atmospheric transport of alkylphenols (David et al. 2009; Ebinghaus and Xie 2006; Lewandowska et al. 2012). Due to the hydrophobic nature of OP and NP, marine bottom sediments should be considered as a sink for these constituents. Anoxic regions of the sea bottom in particular are likely to accumulate alkylphenols because anoxic condition preserves OP and NP and favors formation of these constituents by decomposition of their ethoxylates (Ying et al. 2002).

In this study, we examined sediment age and concentration of alkylphenols in sediment cores from deepwater areas of the Baltic Sea. In these areas, relatively stable sedimentation occurs and sediment composition reflects long-term trends in natural and anthropogenic terrestrial runoff and atmospheric deposition. Dating of sediments combined with the measurements of chemical composition of sediment cores have been frequently used to reconstruction pollution history in industrialized countries (e.g., Kumata et al. 2000; Van Metre and Mahler 2005; Isobe et al. 2001). It is crucial for the understanding of pollution mechanisms and for establishing effective countermeasures against pollution.

The Baltic Sea is the largest brackish water body in the world. The factors such as restricted water exchange, water stratification, oxygen deficiency in deep waters, shallow depths (mean depth $=53 \mathrm{~m}$ ), and a large ratio of catchment area to the surface of the sea $(4: 1)$, cause the Baltic Sea to be sensitive to human pressure (Håkanson and Bryhn 2008; Wulff et al. 2001). Agricultural and industrial catchment areas have led to considerable degradation of the sea. Accurate information about the consumption and production of NP, OP and their ethoxylates in the Baltic Sea catchment as well as the runoff of these components in to the sea is lacking (HELCOM 2010). Since 2005, the NP and nonylphenol ethoxylates are restricted from use in cleaning products at concentrations exceeding $0.1 \%$, by the EU Directive (HELCOM 2010; Cox and Drys 2003). Apart from this, some European countries have introduced additional bans and restrictions on the use of NP and OP. However, neither their production and import, nor the import of products containing these compounds is prohibited. Therefore, it is not surprising, that alkylphenols were detected in water, certain organisms, and sediments (Staniszewska et al. 2014; 2015; Koniecko et al. 2014) of the Baltic Sea. Until now, $\mathrm{NP}$ and OP were determined both in coastal and in offshore regions of the Baltic Sea but only in the surface layer of sediments $(1$ or $2 \mathrm{~cm})$. It has given just a "snapshot" of the current pollution status and no information on the historical trend of pollution in the region has been available.

\section{Materials and methods}

\section{Sample collection and cores processing}

Sediment samples were collected at four sampling stations located in the southern Baltic Sea: on the S-W slope of the Gotland Deep (P140, depth $=88 \mathrm{~m})$; in the Bornholm Deep (P5, depth=86 m), in the Gdansk Deep (P1, depth $=106 \mathrm{~m})$; and on the slope of the Gdansk Deep (P110, depth $=70 \mathrm{~m}$ ) (Fig. 1, Table 1). The samples were taken onboard $\mathrm{r} / \mathrm{v}$ Baltica, with a Niemisto-type corer, in June 2014.

Six sediment cores were collected from each sampling area. Cores were divided into 1- or 2-cm layers within the uppermost $25 \mathrm{~cm}$. The segments of equal depth from three cores were pooled together and frozen. Such procedure allows to get a weight of samples required to obtain assumed limit of quantification and the uncertainty of sediment dating method with ${ }^{210} \mathrm{~Pb}$ (Suplińska and Pietrzak-Flis 2008; Zalewska et al. 2015). Furthermore, vertical heterogeneity of the sediment chemical composition is included. Alkylphenol content and sediment age determination were done in the first set of three integrated cores. Granulometry, water content, and loss on ignition have been analyzed in the second set of three integrated cores from a given area. Additionally, the sediment core for Eh measurements was collected and cut into $2.5-\mathrm{cm}$ layers (in the $0-10 \mathrm{~cm}$ section of the core) and into $5-\mathrm{cm}$ layers (in the $>10 \mathrm{~cm}$ section of the core).

\section{Sediment parameters: redox potential, granulometry, water content, loss on ignition}

Laboratory analyses involved general sediment properties, such as water content $(W)$, loss on ignition (LOI), redox potential (Eh), and grain-size distribution. Redox potential was measured as soon as possible after core retrieval, onboard the research vessel, using an Eh-meter (Microscale Measurements, The Netherlands, model: MB II mV). Slicing of sediment core lasted about 5 min. Each segments of sediment were placed in containers. Before closing, the containers were flushed with 
Fig. 1 Map of the study area

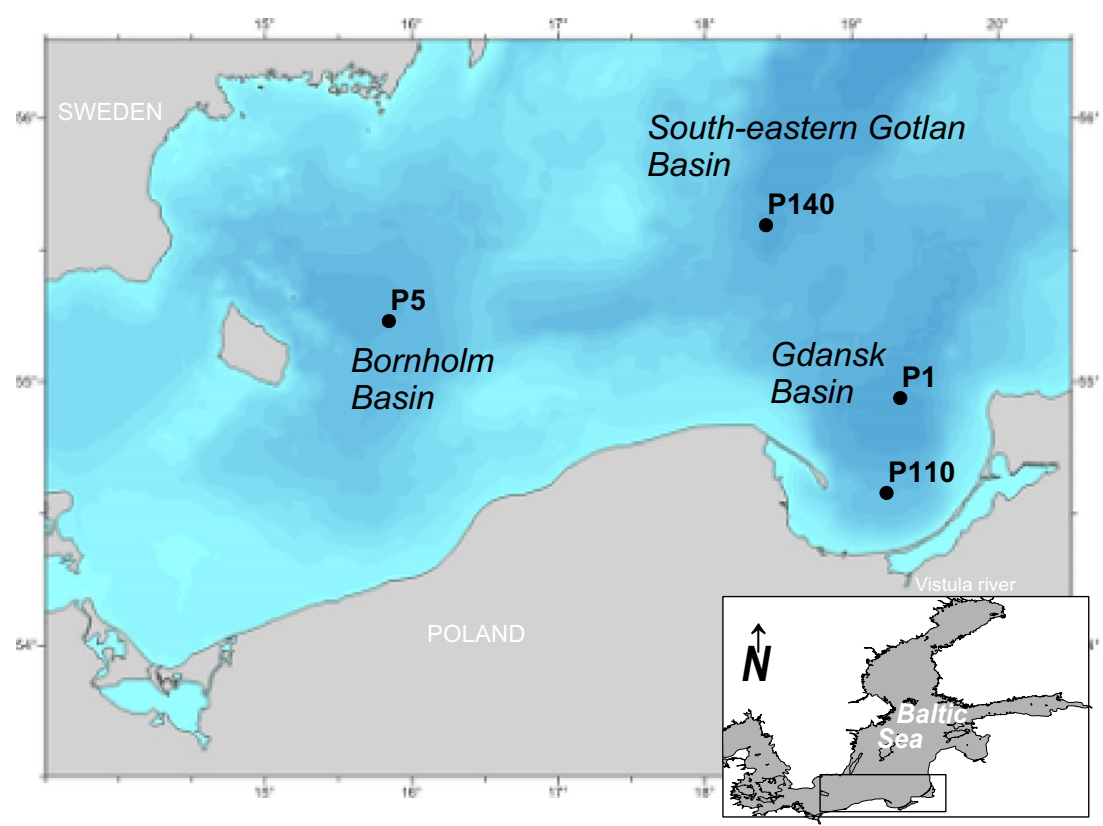

nitrogen. During the measurements, the needle of the electrode was inserted in the middle part of segment. Measurement of Eh in one segment lasted about 10$15 \mathrm{~min}$ (the stabilization time of the electrode).

Water content $(W \%)$ and loss on ignition (LOI \%) were determined by drying the sediment samples to constant weight at 105 and $450{ }^{\circ} \mathrm{C}$, respectively. Granulometric analysis was conducted by sieving dry sediment through a FRITSCH $\mathrm{GmbH}$ metal sieves set consisting of 2.00, 1.00, 0.50, 0.25, 0.125 , and $0.063 \mathrm{~mm}$ net dimensions.

\section{Sediment age determination (sediment dating with ${ }^{210} \mathrm{~Pb}$ )}

\section{Spectrometric analysis}

The freeze-dried sediment samples were homogenized (slices from three integrated cores) prior to the exact analysis. The samples were placed in plastic containers.
The activity concentrations of ${ }^{210} \mathrm{~Pb},{ }^{137} \mathrm{Cs},{ }^{214} \mathrm{Bi}$, and ${ }^{214} \mathrm{~Pb}$ were analyzed by high-resolution gamma spectrometry using an HPGe detector with a relative efficiency of $40 \%$ and a resolution of $1.8 \mathrm{keV}$ for the peak of $1332 \mathrm{keV}$ of ${ }^{60} \mathrm{Co}$. The detector was coupled to an 8192-channel computer analyzer (GENIE 2000). The time of measurements was 80,000 s for each sample. ${ }^{210} \mathrm{~Pb}$ was determined by gamma emission at $46.5 \mathrm{keV},{ }^{226} \mathrm{Ra}$ was determined by the emission of its daughter nuclides ${ }^{214} \mathrm{~Pb}$ and ${ }^{214} \mathrm{Bi}$ at 352 and $609 \mathrm{keV}$, respectively, and ${ }^{137} \mathrm{Cs}$ was measured via its emission at $661.6 \mathrm{keV}$. A mixture of gamma-emitting isotopes-"mix gamma" (Isotope Production and Distribution Center, Swierk, Poland, BW/Z$62 / 27 / 07)$, was used for the calibration.

\section{Mass accumulation rate, linear accumulation rate, and sediment age calculations}

Total amount of radioactive ${ }^{210} \mathrm{~Pb}$ isotope $\left({ }^{210} \mathrm{~Pb}\right.$ tot $)$ that can be found in sediments is the sum of ${ }^{210} \mathrm{~Pb}$ originating from the radioactive decay of radium $\left({ }^{226} \mathrm{Ra}\right)$, which

Table 1 Characteristics of sediments and near-bottom waters in the area of study

\begin{tabular}{llllll}
\hline Region & Station & $\begin{array}{l}\text { Water depth } \\
(\mathrm{m})\end{array}$ & $\begin{array}{l}\text { Salinity in } \\
\text { near- } \\
\text { bottom } \\
\text { water }\end{array}$ & $\begin{array}{l}\text { Oxygen } \\
\left(\mathrm{ml} \mathrm{l}^{-1}\right)\end{array}$ \\
\hline Gdansk Deep & P1 & 106 & 12.26 & 2.03 & Sediment type* \\
Slope of the Gdansk Deep & P110 & 70 & 9.72 & 3.97 & Clays and silty clays \\
S-W Gotland Deep & P140 & 88 & 12.35 & 3.93 & Clays and silty clays \\
Bornholm Deep & P5 & 86 & 16.52 & 2.61 & Clays and silty clays \\
\hline
\end{tabular}

*Kramarska et al., 1995 
is called supported ${ }^{210} \mathrm{~Pb}\left({ }^{210} \mathrm{~Pb}_{\text {supp }}\right)$, and ${ }^{210} \mathrm{~Pb}$ originating from the atmospheric deposition, which is called unsupported or excess ${ }^{210} \mathrm{~Pb}_{\mathrm{ex}}$. The activity of ${ }^{210} \mathrm{~Pb}_{\text {supp }}$ along the sediment profile is approximately constant, while the activity of ${ }^{210} \mathrm{~Pb}_{\text {ex }}$ decreases down the profile and this decrease is usually exponential. As a result, ${ }^{210} \mathrm{~Pb}_{\text {ex }}$ distribution along the sediment profile is used to calculate mass accumulation rate (MAR), linear accumulation rate (LAR), and the age of sediment. These calculations are based on constant flux/constant sedimentation rate (CF/CS) model) (Appleby 1997; Robbins 1978; Bierman et al. 1998; Szmytkiewicz and Zalewska 2014). Results of sediment dating were verified based on ${ }^{137} \mathrm{Cs}$ profiles in sediment. The LAR expresses an average thickness of a layer that is formed within 1 year, while the MAR corresponds to an average mass of sediment deposited on the area of $1 \mathrm{~m}^{2}$ within 1 year. Concentrations of radioactive ${ }^{210} \mathrm{~Pb}_{\mathrm{ex}}$ in the analyzed sediment layers were determined as the difference between concentrations of ${ }^{210} \mathrm{~Pb}_{\text {tot }}$ and ${ }^{214} \mathrm{Bi}$. The average concentration of ${ }^{214} \mathrm{Bi}$ for all the analyzed layers in a core was assumed as the ${ }^{214} \mathrm{Bi}$ value for a particular core.

\section{Alkylphenols}

In the analysis of alkylphenols, the following reagents were used: water, acetonitrile, methanol HPLC grade (Merck), and high grade standards of 4-nonylphenol and 4-tert-octylphenol ( $>97 \%$ of purity; Sigma-Aldrich). Lyophilized sediment samples ( $2 \mathrm{~g}$ from each slice of three integrated cores) were extracted twice with a mixture of deionized water and methanol (30:70) in an ultrasonic bath. The combined extracts were purified on SPE C18 columns using a method developed by Nunez et al. (2007) and Koniecko et al. (2014). Elution was carried out with methanol and acetonitrile. The obtained solutions were dried in a rotary evaporator and reconstituted in $200 \mu \mathrm{dm}^{3}$ of acetonitrile. The final stage of the analysis of alkylphenols was conducted using a high-performance liquid chromatograph Dionex UltiMate 3000 with a fluorescence detector (exCitation $\lambda=275 \mathrm{~nm}$, emission $\lambda=300 \mathrm{~nm}$ ) and a Thermo Scientific HYPERSIL GOLD C18 PAH chromatography column $(250 \times 4.6 \mathrm{~mm} ; 5 \mu \mathrm{m})$ in the mobile phase program (water/acetonitrile) in gradient conditions.

The linear correlation coefficient $r$ for the analytical curves of working solutions $\left(10,25,50,75\right.$, and $\left.100 \mathrm{ng} \mathrm{cm}^{-3}\right)$ was 0.999 . The limit of quantification (LOQ) was $0.08 \mathrm{ng} \mathrm{g}^{-1} \mathrm{dw}$ for both alkylphenols. The background value was below the quantification level. Recovery of both studied compounds was determine in a sediment sample spiked with a known amount of the standard and mean value was $94 \%$ (OP) and $81 \%$ (NP). The precision, expressed as the relative standard deviation coefficient (RSD) for five repetitions of the same sample, was below $8 \%$ for each of the compounds.

\section{NP and OP inventory of sediment}

Based on the obtained results, inventories of NP and OP of the sediment were assessed. The inventory was defined as the total amount $(\mu \mathrm{g})$ of pollutants per area $\left(\mathrm{m}^{2}\right)$, deposited since the 1920 s of the twentieth century. The inventories $(I)$ were calculated according to Eq. 1:

$\mathrm{I}=\sum_{\mathrm{n}=1}^{\mathrm{n}=10 \text { or12or13 }}(100-\mathrm{W}) * 100^{-1} * \mathrm{~h} * \mathrm{~d} * \mathrm{C}$

where $I=\mathrm{NP}$ or OP inventory $\left(\mu \mathrm{g} \mathrm{m}^{2}\right), n=$ the number of sediment segments (depends on the sediment age), $W=$ sediment water content (\%), $h=$ thickness of sediment layer (m), $d=$ average sediment bulk density $\left(26010^{5} \mathrm{~g} \mathrm{~m}^{-3}\right)$, and $C=\mathrm{NP}$ or OP concentration in given segment of sediment (ng $\mathrm{g}^{-1} \mathrm{dw}$ ).

\section{Statistical analysis}

The statistical analysis and visualization of the results was carried out using the STATISTICA 10 by Stat Soft and Microsoft Office Excel 2007.

\section{Results}

\section{Sediment characteristics}

\section{Water content}

Water content of the sediments varied within a relatively narrow range, from 59 to $82 \%$ (Fig. 2). The highest range of water content (from 55 to $79 \%$ ) was observed in the Gdansk Deep (station P1), the lowest one (from 71 to $76 \%$ ) in Bornholm Deep (station P5). In sediments of all studied stations, water content regularly decreased with sediment depth (Fig. 2).

\section{$L O I$}

LOI in the uppermost $1 \mathrm{~cm}$ of the sediment varied from 9.5 to $17.5 \%$ (Fig. 2), and was never lower than $7.1 \%$ in deeper sediment layers. A decrease in LOI down the sediment profile was typical in the Gdansk Deep (P1) and on its slope (P110). In the other regions, the changes of LOI in sediment profiles were irregular, without any general increasing or decreasing trends. In the area of the Gdansk Deep (P1) and its slope (P110), LOI values in surface sediments $(0-3,0-4 \mathrm{~cm})$ were several percent higher than in the other areas (Fig. 2). 


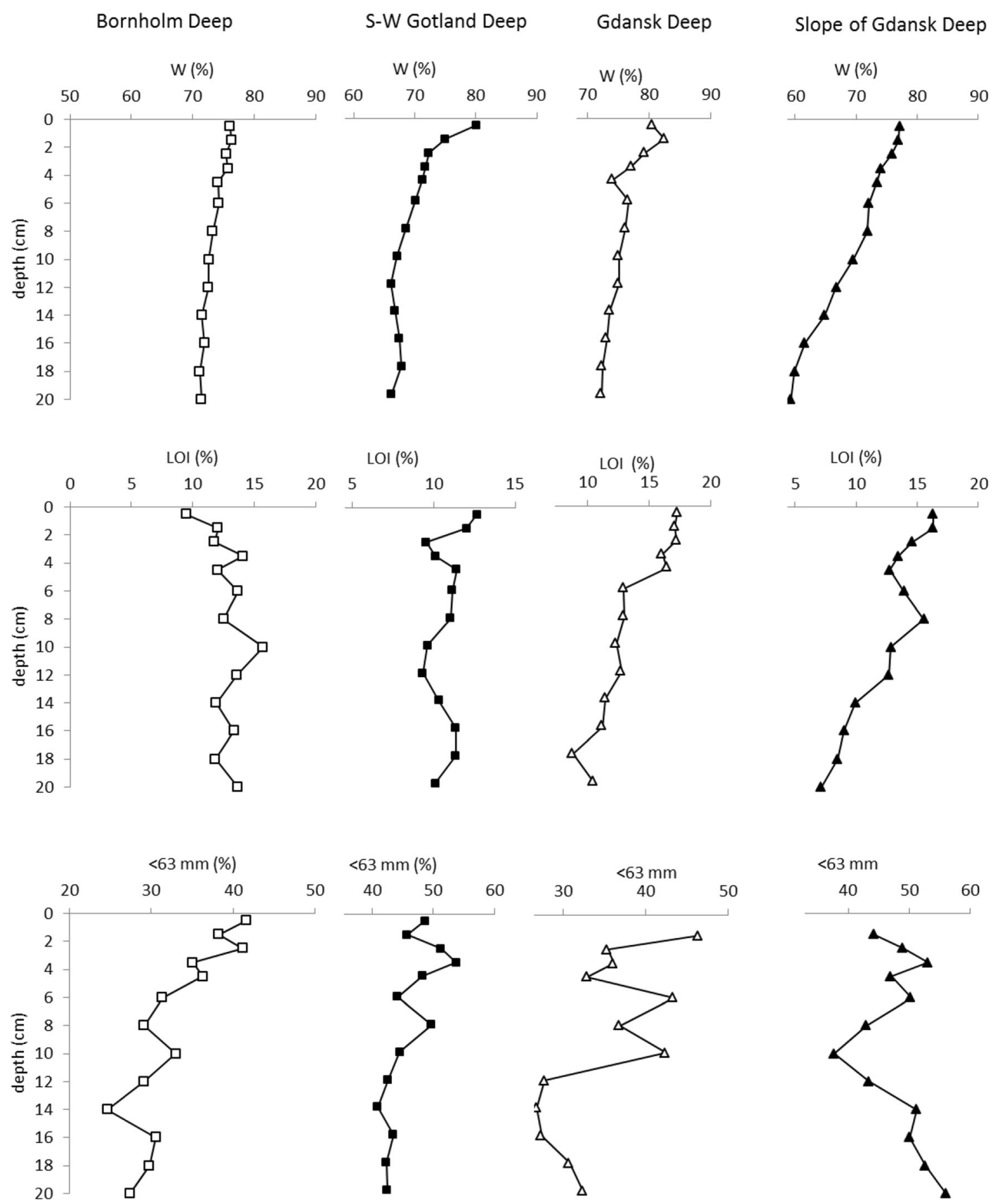

Fig. 2 Profiles of water content $(W)$, loss on ignition (LOI), and the percentage of $<63 \mu \mathrm{m}$ fraction in sediments

\section{Contribution of the $<0.063 \mathrm{~mm}$ fraction}

Contribution of the $<0.063 \mathrm{~mm}$ fraction varied from 25 to $57 \%$. In the first centimeter of the sediment, the fraction below $0.063 \mathrm{~mm}$ constituted from 42 to $47 \%$ of all fractions. In all regions, expect of slope of Gdansk Deep, contribution of $<0.063 \mathrm{~mm}$ fraction decreased irregularly with sediment depth (Fig. 2). At the slope of the Gdansk Deep (P110), the changes was irregularly with no clear trends. The highest range of
$<0.063 \mathrm{~mm}$ fraction (from 26 to $47 \%$ ) was observed in the Gdansk Deep (station P1).

\section{Eh}

The Eh potential of sediments decreased approximately exponentially in sediment profiles (Fig. 3). Reducing conditions $(E h<100 \mathrm{mV}$ ) were observed below the 3$4 \mathrm{~cm}$ of sediment, except for the station located on the 


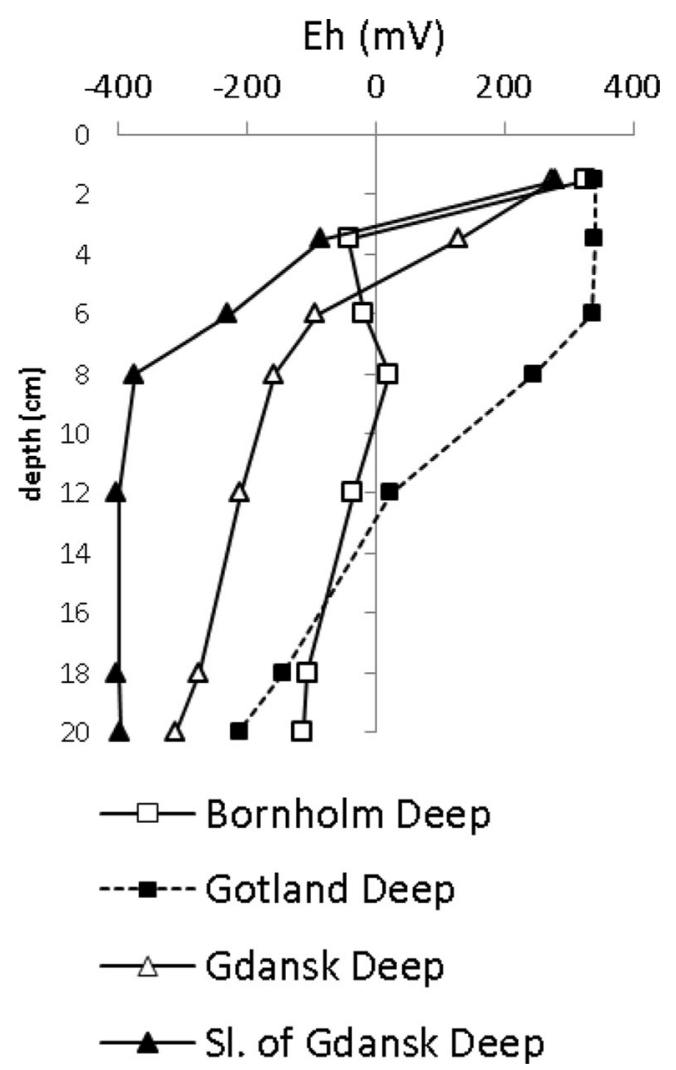

Fig. 3 Profiles of Eh in sediments

slope of the Gotland Deep (P140), where they appeared below the layer of 7-9 $\mathrm{cm}$ below sediment surface (Fig. 3).

\section{Sedimentation rate}

Linear and mass accumulation rates increased in the following order: Gdansk Deep, slope of the Gdansk Deep, S-W Gotland Deep, Bornholm Deep (Table 2). Profiles of ${ }^{210} \mathrm{~Pb}_{\exp }$ and ${ }^{137} \mathrm{Cs}$, used for the calculation and verification of the obtained results, can be found in supplementary materials (Figs. $1 \mathrm{~S}$ and $2 \mathrm{~S}$ ).

Table 2 Linear accumulation rate (LAR) and mass accumulation rate (MAR) in sediments of the study area

\begin{tabular}{lll}
\hline Region & $\begin{array}{l}\text { Linear accumulation } \\
\text { rate } \\
\text { mm year }\end{array}$ & $\begin{array}{l}\text { Mass accumulation } \\
\text { rate } \\
\mathrm{g} \mathrm{m}^{-2} \text { year }^{-1}\end{array}$ \\
\hline Bornholm Deep & 3.0 & 979 \\
S-W Gotland Deep & 2.0 & 800 \\
Gdansk Deep & 1.6 & 470 \\
Slope of the Gdansk Deep & 1.8 & 749 \\
\hline
\end{tabular}

\section{Alkylphenols}

\section{NP concentrations}

NP concentrations ranged from $<\mathrm{LOQ}$ to $239.88 \mathrm{ng} \mathrm{g}^{-1} \mathrm{dw}$ of sediment (Table 3$)$. In the surface layer $(0-1 \mathrm{~cm})$, they varied between 15.80 and $239.88 \mathrm{ng} \mathrm{g}^{-1} \mathrm{dw}(99.72$ $\left.\pm 97.07 \mathrm{ng} \mathrm{g}^{-1} \mathrm{dw}\right)$. Clear spatial differences in the content of NP were observed in the layers from the sediment surface to the 5-7 $\mathrm{cm}$ below sea floor. The highest values were reported in sediments of the S-W Gotland Deep (P140) (Fig. 4a) and the lowest on the slope of the Gdansk Deep (P110). In sediments of the Gdansk Deep and Bornholm Deep, NP concentrations in surface sediments were similar, while in deeper sediment layers, higher values were measured in the area of the Bornholm Deep.

In the deepest sediment layers which, depending on the region, corresponded to the period from 1867 to 1929, NP concentrations ranged from $<$ LOQ to about $2 \mathrm{ng} \mathrm{g}^{-1} \mathrm{dw}$. In the area of the Bornholm Deep and S-W Gotland Deep, NP concentrations increased up the sediment column, beginning from the depth corresponding to the early 1960 s of the last century. A rapid increase in the concentrations was observed from the years 2000 and 1988, respectively, for the Bornholm Deep and for the S-W Gotland Deep. In the area of the Gdansk Deep, the concentrations started to increase in the end of the 1950s of the last century. The particularly strong growth of NP in this region began in the mid-1970s. On the slope of the Gdansk Deep, the increase started in 1983. In the first decade of the twentyfirst century, a short-term decrease in the concentrations was reported in this region. However, since 2010, the NP levels have gone up again.

\section{OP concentrations}

OP concentrations were from $<$ LOQ to $13.01 \mathrm{ng} \mathrm{g}^{-1} \mathrm{dw}$ of sediment (Table 3$)$. In the surface layer $(0-1 \mathrm{~cm})$ they ranged from 5.61 to $13.01 \mathrm{ng} \mathrm{g}^{-1} \mathrm{dw}(9.07$ $\left.\pm 3.11 \mathrm{ng} \mathrm{g}^{-1} \mathrm{dw}\right)$. Spatial differences in the content of OP were observed in the whole profile, and they were the greatest in top 5-7 cm (Fig. 4b). The highest values were determined in sediments of the S-W Gotland Deep. Relatively high values were also reported for sediments of the Bornholm Deep. In the area of the Gdansk Deep and the slope of the Gdansk Deep, OP concentrations were similar and, in most sediment layers, lower than in the other areas. The $0-1 \mathrm{~cm}$ sediment layer of the slope of the Gdansk Deep was the exception as the concentration of OP at that site amounted to $10 \mathrm{ng} \mathrm{g}^{-1} \mathrm{dw}$, which was lower only than 
Table 3 The outcome of the statistical analysis of OP and NP content in sediments of the study area (sediment layer 0-25 cm)

\begin{tabular}{|c|c|c|c|c|c|c|c|}
\hline & Region & Number & Mean $\pm \mathrm{SD}$ & Min-max & Median & $\begin{array}{l}\text { Lower } \\
\text { quartile }\end{array}$ & $\begin{array}{l}\text { Upper } \\
\text { quartile }\end{array}$ \\
\hline \multirow[t]{4}{*}{$\mathrm{NP}\left(n g g^{-1} \mathrm{dw}\right)$} & Bornholm Deep & 13 & $14.04 \pm 21.50$ & ND-71.92 & 3.21 & 1.64 & 22.88 \\
\hline & S-W Gotland Deep & 13 & $68.67 \pm 95.50$ & $0.43-239.88$ & 8.09 & 1.51 & 170.08 \\
\hline & Gdansk Deep & 13 & $27.39 \pm 30.60$ & $0.71-74.59$ & 5.60 & 2.07 & 57.36 \\
\hline & Slope of the Gdansk Deep & 13 & $2.47 \pm 4.53$ & ND-15.80 & 0.59 & 0 & 2.96 \\
\hline \multirow[t]{4}{*}{$\mathrm{OP}\left(n g \mathrm{~g}^{-1} \mathrm{dw}\right)$} & Bornholm Deep & 13 & $3.71 \pm 2.04$ & ND-7.99 & 3.72 & 3.18 & 5.00 \\
\hline & S-W Gotland Deep & 13 & $5.96 \pm 3.77$ & $2.08-13.01$ & 3.99 & 3.38 & 7.83 \\
\hline & Gdansk Deep & 13 & $1.72 \pm 1.52$ & $0.25-5.61$ & 1.39 & 0.83 & 1.88 \\
\hline & Slope of the Gdansk Deep & 13 & $1.46 \pm 2.55$ & ND-9.68 & 0.58 & 0.40 & 1.58 \\
\hline
\end{tabular}

the value measured in the surface layer of sediments in the S-W Gotland Deep.

In the deepest sediment layers which, depending on the region, corresponded to the period from 1867 to 1929 , OP concentrations ranged from $<$ LOQ in the area of the Bornholm Deep (P5) to about $3 \mathrm{ng} \mathrm{g}^{-1} \mathrm{dw}$ in the area of the S-W Gotland Deep (P140). In sediments of the Bornholm Deep, Gotland Deep, and the Gdansk Deep (together with its slope), the concentration started to increase in the 1950s, 1960s, and 1970s of the last century, respectively. In all the areas, the strongest increasing tendency was observed for sediments of this century. Since 2000 , the concentrations of OP have increased about two-, three-, six,- and fivefold in the

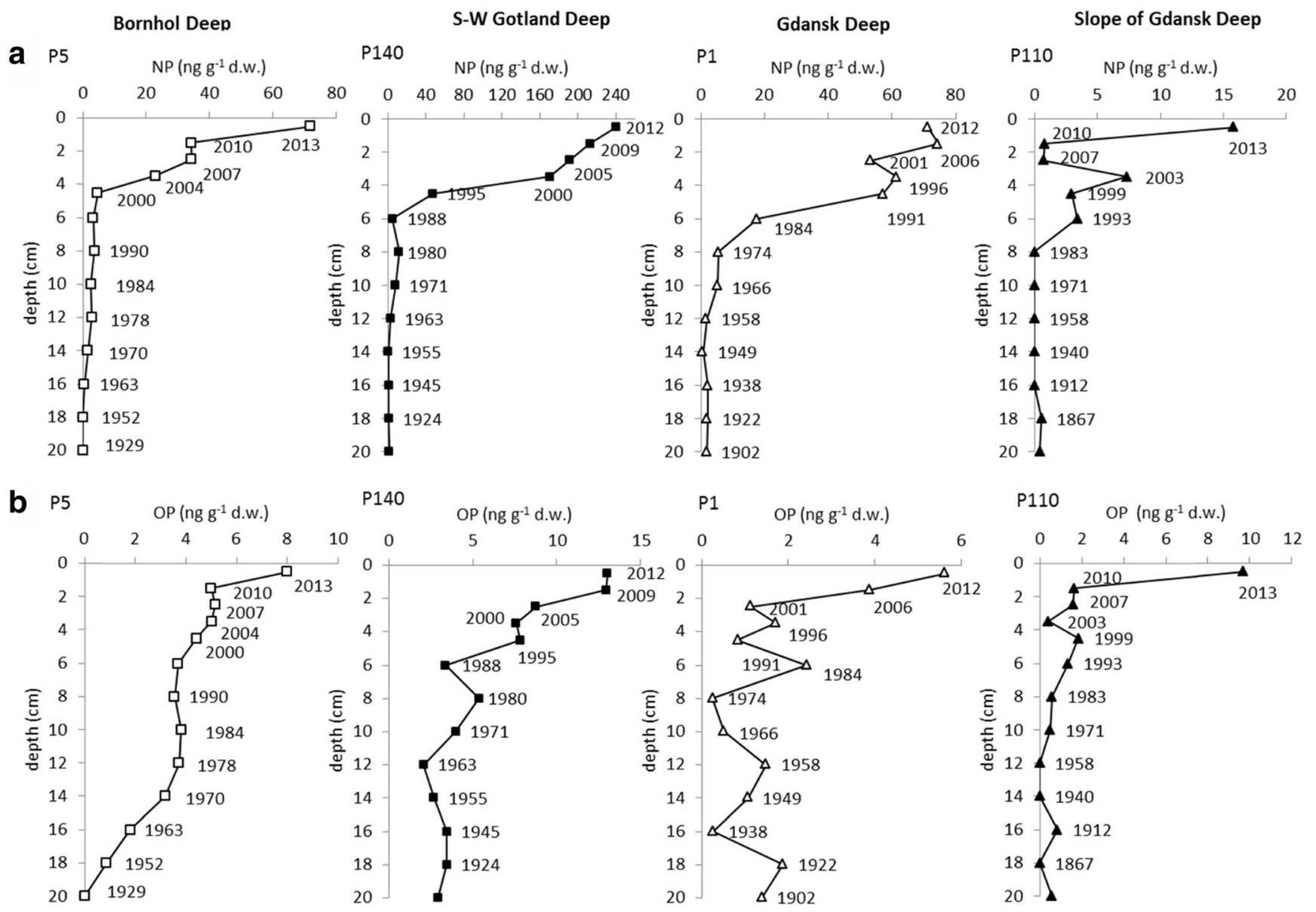

Fig. 4 Profiles of $\mathbf{a}$ NP and $\mathbf{b}$ OP in sediments of the study area 
sediments of the Bornholm Deep, S-W Gotland Deep, Gdansk Deep, and the slope of the Gdansk Deep, respectively.

There was no statistically significant dependences between the concentrations of alkylphenols and LOI ( $r=-0.12, p=0.38$ for OP and $r=0.00, p=0.97$ for NP). A relatively high positive linear correlation between redox potential and both alkylphenols, OP $(r=0.68, p<0.001)$ and NP $(r=0.58, p=0.001)$ was observed. Also, the relationship between the OP and NP was characterized by relatively high coefficient of linear correlation $(r=0.77, p<0.001)$ (Fig. $2 \mathrm{~S})$.

\section{Discussion}

\section{Regional variability, impact factors and inventories of alkylphenols}

Due to the small amount of literature data, it is difficult to compare OP and NP levels obtained in this study with other open sea areas of the Baltic Sea. The NP concentrations obtained in the present study for surface layer of sediments are high as compared with concentration of NP in surface sediments from offshore sites of the Swedish sub-basins (Table 4). Moreover, the levels measured in the area of the Gotland Deep exceeded the predicted no-effect concentration (PNEC) value adopted by HELCOM (2010), which amounts to $180 \mathrm{ng} \mathrm{g}^{-1} \mathrm{dw}$. The PNEC is the concentration below which exposure to a substance is not expected to cause adverse effects. Presented value of PNEC (180 ng g ${ }^{-1} \mathrm{dw}$ ) is calculated as a product of a partition coefficient suspended matterwater and the PNEC in water, divided by the bulk density of suspended matter (for details see Anonymous 2005a; Lepper 2005). Usually, the PNEC is calculated using toxicity data. However, eco-toxicological data of PNEC for NP and OP, concerning the sediment and biota, are lacking. Calculation of PNEC based on the equilibrium partitioning method, has some limitations compared to PNEC estimate based on eco-toxicological data. The equilibrium partitioning approach only considers uptake via the water phase. However, uptake may also occur via other exposure pathways like

Table 4 Concentration of 4-nonylphenol and 4-tert-octylphenol $\left(\mathrm{ng} \mathrm{g}^{-1} \mathrm{dw}\right)$ in surface layer of sediments in different bodies of water in the world

\begin{tabular}{|c|c|c|c|c|}
\hline & Region & $\mathrm{NP}\left(n g \mathrm{~g}^{-1} \mathrm{dw}\right)$ & $\mathrm{OP}\left(\mathrm{ng} \mathrm{g}^{-1} \mathrm{dw}\right)$ & References \\
\hline \multirow[t]{13}{*}{ Europe } & $\begin{array}{l}\text { Costal Baltic Sea, The Gulf of } \\
\text { Gdańsk (Poland) }\end{array}$ & $0.08-49$ & $0.08-250$ & Koniecko et al. 2014 \\
\hline & Offshore Baltic Sea & $\begin{array}{c}<3 \text { to } 65 \text { (not detected } \\
\text { at } 10 \text { out of } 14 \\
\text { investigated sits) }\end{array}$ & $\begin{array}{l}<3-110 \text { (not detected } \\
\text { at } 5 \text { out of } 14 \text { sites) }\end{array}$ & Cato and Kjellin 2005; 2008 \\
\hline & $\begin{array}{l}\text { Offshore Baltic Sea (the Gotland, } \\
\text { Bornholm, Gdansk Deeps) }\end{array}$ & $16-240$ & $5.6-13$ & This work \\
\hline & $\begin{array}{l}\text { Costal Baltic Sea } \\
\text { Espoo (Finland) }\end{array}$ & 2.2 & $<0.2$ & Hansen and Lassen 2008 \\
\hline & $\begin{array}{l}\text { Costal Baltic Sea } \\
\text { Oslo Fjord (Norway) }\end{array}$ & $<0.2$ & $<0.2$ & Hansen and Lassen 2008 \\
\hline & North Atlantic, Faroe Islands & $0.7-3.1$ & 24.8 & Hansen and Lassen 2008 \\
\hline & Costal North Sea, German Bight (Germany) & $<10-55$ & & Bester et al. 2001 \\
\hline & $\begin{array}{l}\text { Costal North Sea, Dutch estuaries } \\
\text { (The Netherland) }\end{array}$ & $0.9-1080$ & & Jonkers et al. 2003 \\
\hline & Costal Aegean Sea, Thermaikos Bay (Greece) & 266 & & Arditsoglou and Voutsa 2012 \\
\hline & Costal Adriatic Sea, Venice Lagoon (Italy) & $47-132$ & & Pojana et al. 2007 \\
\hline & Mediterranean Sea (Spain) & $18-590$ & & Petrovic et al. 2002 \\
\hline & Coast Atlantic (Spain) & $23-1050$ & & Petrovic et al. 2002 \\
\hline & Coast Atlantic, Cadiz Bay (Spain) & $13-225$ & & Lara-Martin et al. 2006 \\
\hline \multirow[t]{4}{*}{ Asia } & Coast China Sea (Taiwan) & $130-190$ & $27-49$ & Chen et al. 2005 \\
\hline & Coast China Sea, Masan Bay (Korea) & $113-3890$ & $4-179$ & Khim et al. 1999 \\
\hline & Coast Pacific Ocean, Tokyo Bay (Japan) & $120-640$ & $6-100$ & Isobe et al. 2001 \\
\hline & Coast Pacific Ocean, Tokyo Bay (Japan) & $142-20,700$ & & Kurihara et al. 2007 \\
\hline \multirow{3}{*}{$\begin{array}{l}\text { North } \\
\text { America }\end{array}$} & Coast Caribbean Sea, Jamaica Bay (USA) & $7-13,700$ & $2.4-45$ & Ferguson et al. 2001 \\
\hline & Coast Pacific Ocean, Southern California Bight (USA) & $130-3200$ & $1.9-8.2$ & Schlenk et al. 2005 \\
\hline & Coast Atlantic, Marsh-estuaries Savannah (USA) & $10.0-18$ & $2.6-6.9$ & Senthil Kumar et al. 2008 \\
\hline
\end{tabular}


ingestion of sediment and direct contact with sediment (Anonymous 2005b). Concentrations of NP obtained in the present study were also greater than, for example, the values in the surface layer of the German Bight sediments and lower than concentrations in most of the basins located along highly urbanized coasts of Asia and North America (Table 4).

The concentrations of OP obtained in the present study (5.61 to $13.01 \mathrm{ng} \mathrm{g}^{-1} \mathrm{dw}$ ) for surface sediments $(0-1 \mathrm{~cm}$ ) were average or high as compared with the values in the surface layer of offshore Baltic sediments (Table 4). In all areas investigated in this study, OP concentrations exceeded the predicted no-effect concentration (PNEC) of $3.4 \mathrm{ng} \mathrm{g}^{-1} \mathrm{dw}$ adopted by HELCOM (2010), estimated on the basis of the equilibrium partitioning method (Anonymous 2005b). However, the concentrations were much lower than, for example, in sediments off the coast of Japan and America, and comparable to those recorded in the Pearl River Estuary and South China Sea (Table 4).

The studies on the kinetics of OP sorption in sediments showed that it is a two-step process. The first step includes fast sorption on the surface. After that, a slow interparticle sorption takes place (Zhou 2006). Probably, alkylphenol fraction which is interpartically sorbed cannot be entirely measured using a standard extraction procedure. This was indicated in the study by Milinovič et al. (2015), who developed the NP sequence analysis. Their research showed that in sediments of the Bohai Bay (North China Sea), non-extractable (interpartically sorbed) NP constituted $38-99 \%$ of total NP. In the present work, similarly as in other previous studies, alkylphenols were extracted using the standard solvent mixture (methanol and water). Hence, it is probable that the results obtained so far (in this study and in similar previous studies) were underestimated as they did not include interpartically sorbed fraction. It is therefore important to apply new sequence analysis in future studies.

Numerous studies, especially experimental ones, indicated that the fraction of organic carbon is an important parameter that can have an influence on the sorption of alkylphenols and other organic contaminants in sediments (Milinovič et al. 2015; Mayer 1993; John et al. 2000). Lack of significant relationships between LOI and alkylphenols in presented study was presumably the result of the complex nature of processes controlling alkylphenol sorption in environmental condition. It can be assumed that in the case of sediments similar to those in the study area, fine-grained and rich in organic matter, the composition of organic matter, e.g., black carbon content (Koniecko et al. 2014), occurrence of colloids (Zhou 2006), and degree of organic matter decomposition, are crucial for the sequestration of NP and OP in sediments. The effect of the latter seems to be confirmed by a relatively high positive linear correlation between redox potential and both alkylphenols. But this is probable connected to the fact that the amount of
OP and NP is very low in the deep sediment layers, since they were sedimented before the onset of alkylphenols industrial production and the Eh is always negative because are anoxic sediment layer. When Eh increases toward sediment surface because of a higher oxygen availability, NP and OP does it because their sedimentation rate increase since are more recent layers.

Relatively high relationship between OP and NP observed in this study may indicate the same or similar sources of these compounds to the marine environment. However, based on the scatter plot, we can see that the high value of $r$ coefficient was caused by only four results (Fig. 3S). The NP is supplied to the marine environment probably mainly with sewage containing NPEs. In the case of OP, its important source can be dust formed by abrasion of tires. According to COHIBA (2011a), more than $50 \%$ of the OP external load is introduced to the Baltic Sea in this way, although this is disputed by tire manufacturers. The producers claim that $\mathrm{OP}$ is used in resins inside the layers and not on the tire tread. However, when tires are mechanically crushed, OP can be potentially released. The set of results obtained in the present study did not allow any definite conclusions to be drawn on dependences between NP and $\mathrm{OP}$, more results and further research is needed.

The concentration of organic contaminants in sediments depends, among others, on their supply from the catchment area, their sorption and degradation processes in sediments, and hydrodynamic conditions. The hydrophobic nature of the analyzed compounds $\left(K_{\mathrm{o} / \mathrm{w}}=4.12\right.$ and 4.48 , for OP and NP, respectively) causes that they are probably supplied to the bottom mainly with the suspended matter. In the study area, its inflow to the sediments occurs through the vertical as well as horizontal transport. Contaminants which reach bottom sediments are "diluted" by bioturbation and total sediment accumulation rates (Jonsson 2000). In order to compare the investigated sites in terms of the final sink for NP and OP, the inventories of OP and NP were calculated (Table 5). That approach enabled to disregard the influence of dilution and allowed a real comparison of the deposited amounts of alkylphenols.

The S-W Gotland Deep showed clearly higher amounts of the measured contaminants than the other areas. In contrast, the inventory of NP was almost twice of that reported in the Bornholm Deep. On the contrary, the inventory of OP was three times lower than in the Bornholm Deep. The smallest
Table 5 Calculated inventories $(I)$ of NP and OP

\begin{tabular}{lll}
\hline Region & $\begin{array}{l}\text { NP } \\
\mu \mathrm{g} \mathrm{m}^{2}\end{array}$ & OP \\
\hline Bornholm Deep & 126 & 47 \\
S-W Gotland Deep & 610 & 74 \\
Gdansk Deep & 210 & 17 \\
Slope of the Gdansk Deep & 24 & 16 \\
\hline
\end{tabular}


amounts of OP and NP were deposited on the slope of the Gdansk Deep. The spatial variability of the pollutant inventories did not match the observed linear and mass accumulation rates. This indicates differences in the quality of material supplied to the bottom and/or differences in the retention of alkylphenols in the study area. The main reason for the observed variability could be the uplift of the Baltic Sea floor. The land uplift in the Baltic region varies from about $9 \mathrm{~mm}$ year $^{-1}$ in the northern part of the sea to about 0 in the southern-central part of the Baltic Proper (Håkanson and Gyllenhammar 2005). It was shown that land uplift may be responsible for the settling of 50-80\% of the materials below the wave base in the open Baltic Proper (Jonsson et al. 1990; Jonsson 1992; Blomqvist and Larsson 1994; Eckhéll et al. 2000). As a result, at the edge of the Gotland Basin, on the slope of the Gotland Deep (station P140), greater amounts of material from land uplift can be potentially accumulated than in the other study areas. It is worth noting that high concentrations of alkylphenols in the surface sediments of deep-water Gotland Basin areas were observed earlier by Cato and Kjellin 2005. The Gotland Basin has the largest catchment area among all the regions of the Baltic Sea and receives water from highly industrialized Scandinavian countries where, for example, paper and pulp have been produced for decades. This region is also characterized by high intensity of sea transport (off the Swedish coast) (HELCOM 2009). Oil spills and leaching of OP and NP from paints covering the hulls of ships could be a source of alkylphenols to the marine environment (COHIBA 2011a; 2011b). Moreover, extensive blooms of blue-green algae take place regularly in the Gotland Basin, and in its deep-water zones, we can observe permanent oxygen deficiency (e.g., Carstensen et al. 2014). It favors the accumulation of alkylphenols in sediments and formation of OP and NP by decomposition of their ethoxylates (Ying et al. 2002). For 4-nonylphenol, 401 days are required in anaerobic conditions for a complete breakdown of this compound (Heinis et al. 1999). When oxygen is involved, the decomposition of 4-nonylphenol occurs more rapidly, with nearly $50 \%$ of this compound being decomposed within 10 days (Ying et al. 2003).

\section{Historical trends of alkylphenol contamination in sediments}

The synthesis of first phenolic resins was developed in the years 1907-1911. However, octyl- and nonylphenol ethoxylates started to be produced on an industrial scale in the 1930 s and 1940 s, respectively. Since then, the production increased exponentially, especially that of nonylphenol (Fiege et al. 2000). The present study indicated that the contamination of sediments by the NP was pronounced by its increased concentrations in sediments of the accumulation bottom about 20 years after its mass production had started, namely in the 1960s. The 1960s of the twentieth century was a period when first symptoms of eutrophication in the form of significant long-term decreasing trends in oxygen concentrations in deep waters (Fonselius 1969) and increasing concentrations of phosphates appeared in the Baltic Sea. It can be assumed that the increase in the supply of organic matter to the sediments and oxygen depletion resulting from eutrophication, indirectly enhanced alkylphenol accumulation in sediments (Ying et al. 2002). The slope of the Gdansk Deep was the only area where NP accumulation began much later (in the 1980s of the twentieth century). This area is the shallowest of all the investigated in the present study. Due to its depth (about $70 \mathrm{~m}$ ), the bottom of the slope of the Gdansk Deep can be influenced by wind mixing, and thus this area is less conducive to accumulation and long-term oxygen deficiency. Lower accumulation of the analyzed compounds in the sediments of the Gdansk Deep slope could also be the result of significantly lower than in the other areas salinity of near-bottom waters. Experimental studies showed that the sorption of OP is enhanced in the presence of salts (Zhou 2006).

In many works, it was emphasized that NP and OP are of anthropogenic origin (e.g., Chen et al. 2005). Therefore, their presence in sediment layers deposited before the period of their production is surprising. In the present study, their concentrations reached relatively high levels in those layers, particularly in the case of OP. Both NP and OP were detected in European groundwaters (Loos et al. 2010), which indicates their ability to infiltrate despite very high, especially for NP and $K_{\mathrm{o} / \mathrm{c}}$ partition coefficient. It is possible that the mobility of alkylphenols in fine-grained sediments is stimulated by reduction conditions and acidic conditions, similarly as in the case of metals or phosphates (Chuan et al. 1996). Theoretically, OP and NP presence in sediment layers deposited before the period of their production could be also the result of bioturbation or bioirrigation. But in the deep water of the Baltic Sea, macrobenthic organisms are limited and even lacking (Warzocha 1995).'

According to UBA (2006), the production volumes of NP in the EU were reduced by $50 \%$ since 2005 . The NP sediment profiles obtained in the present study did not indicate any response of the ecosystem to decreased external loading of that compound, which suggests potentially large internal load of NPs in the Baltic Sea. The limited exchange of water, as in the study area, is generally conducive to long retention of pollutants. In the present century, an increase in the accumulation was also observed for OP, which production, according to UBA (2006), remained at a similar level to 2005. Increased accumulation of OP and NP in last decade in deep-water areas should be associated with drastic changes in oxygen conditions. Based on the oxygen data from the period of 1960-2011, it was observed that a distinct regime shift occurred in 1999. Before that 
shift, from 1960 to 1999 , hypoxia affected large areas and volumes while anoxic conditions affected only minor deep areas of Baltic Sea. Since the regime shift in 1999, both the areal extent and volume of hypoxia and anoxia have been elevated to levels never recorded before (Hansson et al. 2011).

\section{Summary}

Fine-grained sediments of the study area act as NP and OP sinks. A comparison of the calculated inventories of OP and NP showed clear regional differences, with the highest values in the SE part of the Gotland Deep $\left(610 \mu \mathrm{g} \mathrm{m} \mathrm{m}^{2}\right.$ of NP and $47 \mu \mathrm{g} \mathrm{m}^{2}$ of $\mathrm{OP}$ ) and the lowest values at the slope of the Gdansk Deep ( $24 \mu \mathrm{g} \mathrm{m}^{2}$ of NP and $16 \mu \mathrm{g} \mathrm{m}^{2}$ of OP). Such spatial distribution was probably, among other factors, the result of the uplift of the Baltic Sea floor.

Although in detail the alkylphenols showed individual differences in the vertical distribution, an increase in concentrations since the 1960s/1970s of the twentieth century occurred for most of the studied regions. This period coincides with the first signs of eutrophication in the Baltic.

The youngest deposits, from about the past 10 to 15 years, were usually characterized by sharp increasing trends in the OP and NP, which could be associated with the increase in the areal extent and volume of hypoxia and anoxia in the Baltic Sea. The occurrence of OP and NP in sediment layers deposited before the mass production of alkylphenols could be associated with their infiltration in sediment column.

The results of the present study suggested that concentrations of alkylphenols in sediments were influenced by various complex factors. We can expect that even a considerable decrease in the external supply of alkylphenols to the Baltic Sea will not cause quick improvement of environmental conditions because of eutrophication and oxygen deficits in Baltic, which stimulate accumulation of alkylphenols in sediment.

Acknowledgments This research was founded by the Polish National Science Centre within the framework of the project No. UMO-2012/07/ B/ST10/04281

Open Access This article is distributed under the terms of the Creative Commons Attribution 4.0 International License (http:// creativecommons.org/licenses/by/4.0/), which permits unrestricted use, distribution, and reproduction in any medium, provided you give appropriate credit to the original author(s) and the source, provide a link to the Creative Commons license, and indicate if changes were made.

\section{References}

Ahel M, Giger W, Koch M (1994a) Behaviour of alkylphenol polyethoxylate surfactants in the aquatic environment-I. Occurrence and transformation in sewage treatment. Water Res 28(5):1131-1142

Ahel M, Giger W, Schaffner C (1994b) Behaviour of alkylphenol polyethoxylate surfactants in the aquatic environment-II. Occurrence and transformation in rivers. Water Res 28(5):11431152

Anonymous (2005a) Environmental quality standards (EQS), Substance data sheet priority substance no. 24., p 18

Anonymous (2005b) Environmental quality standards (EQS), Substance data sheet priority substance no. 25., p 18

Appleby PG (1997) Dating of sediments by ${ }^{210} \mathrm{~Pb}$ : problems and solutions, Proc of a seminar dating of sediments and determination of sedimentation rate. STUK, Helsinki, pp A145-A147

Arditsoglou A, Voutsa D (2012) Occurrence and partitioning of endocrine-disrupting compounds in the marine environment of Thermaikos Gulf, Northern Aegean Sea, Greece. Mar Pollut Bull 64:2443-2452

Bester K, Theobald N, Schroder HF (2001) Nonylphenols, nonylphenolethoxylates, linear alkylbenzene sulfonates (LAS) and bis(4chlorophenyl)-sulfone in the German Bigt of the North Sea. Chemosphere 45:817-826

Bierman PR, Albrecht A, Bothner MH, Brown ET, Bullen TD, Gray LB, Turpin L (1998) Erosion, weathering and sedimentation. In: Kendall $\mathrm{C}$, McDonnell JJ (eds) Isotope tracers on catchment hydrology. Elsevier, Amsterdam, pp 647-678

Blomqvist S, Larsson U (1994) Detrital bedrock elements as tracers of settling resuspended particulate matter in a coastal area of the Baltic Sea. Limnol Oceanogr 39:880-896. doi:10.4319/1o.1994.39.4.0880

Carstensen J, Andersen JH, Gustafsson BG, Conley FJ (2014) Deoxygenation of the Baltic Sea during the last century. PNAS 111(15):5628-5633

Cato I, Kjellin B (2005) The National Swedish Status and Trend Monitoring Programme based on chemical contamination in offshore sediment - an overview of the results from 2003. SGUreport 2005:25. In: HELCOM (2009) Hazardous substances of specific concern to the Baltic Sea-Final report of the HAZARDOUS project Balt. Sea Environ. Proc. No. 119

Cato I, Kjellin B (2008) The National Swedish Status and Trend Monitoring Programme based on Chemical Contamination in Offshore Sediment - an overview of the results from 2003 An updated version 2008, SGU Rapport 2008:19. In: OSPAR (2009) Background document on nonylphenol/nonylphenolethoxylates. OSPAR Commision, London. Publication Number: 396/2009. ISBN 978-1-906840-36-5

Chen B, Mai BX, Duan JC, Luo XJ, Yang QS, Sheng GY, Fu JM (2005) Concentrations of alkylphenols in sediments from the Pearl River estuary and South China Sea, South China. Mar Pollut Bull 50:9931018

Chuan MC, Shu GJ, Liu JC (1996) Solubility of heavy metals in a contaminated soil: effects of redox potential and $\mathrm{pH}$. Water Air Soil Poll 90(3-4):543-556

COHIBA (2011a) Guidance Document no. 7 Measures for emission reduction of octylphenol (OP) and octylphenol ethoxylates (OPE) in the Baltic Sea area. In: MarscheiderWeidemann F (ed) COHIBA Project Consorcium, Federal Environment Agency of Germany (UBA)

COHIBA (2011b) Guidance document no. 6 Measures for emission reduction of nonylphenol (NP) and noylphenol ethoxylates (NPE) in the Baltic Sea area. In: Mehtonen J, Munne P (eds) COHIBA Project Consorcium, Federal Environment Agency of Germany (UBA) 
Comber MHI, Williams TD, Stewart KM (1993) The effects of nonylphenol on Daphnia magna. Water Res 27(2):273-276

Cox P, Drys G (2003) Directive 2003/53/EC of the European Parliament and of the council. Off J Eur Communities 17

David A, Fenet H, Gomez E (2009) Alkylphenols in marine environments: distribution monitoring strategies and detection considerations. Mar Pollut Bull 58:953-960

Ebinghaus R, Xie Z (2006) Occurence and air/sea-exchange of novel organic pollutants in the marine environment. J Phys IV France 139:211-237

Eckhéll J, Jonsson P, Meili M, Carman R (2000) Storm influence on the accumulation and lamination of sediments in deep areas of the Northwestern Baltic Proper. AMBIO 29(4):238245. doi:10.1579/0044-7447-29.4.238

Ferguson PL, Iden CR, Brownawell BJ (2001) Distribution and fate of neutral alkylphenol ethoxylate metabolites in a sewage-impacted urban estuary. Environ Sci Technol 35(12):2428-2435. doi:10. 1021/es001871b

Fiege H, Voges HW, Hamamoto T, Umemura S, Iwata T, Miki H, Fujita Y, Buysch HJ, Garbe D, Paulus W (2000) Phenol derivatives, Ullmann's encyclopedia of industrial chemistry. Wiley, Weinheim. doi:10.1002/14356007.a19 313

Fonselius SH (1969) Hydrography of the Baltic deep basins III. Fish Board Swed Ser Hydrogr 23:97

Håkanson L, Bryhn AC (2008) Eutrophication in the Baltic Sea: present situation, nutrient transport processes, remedial strategies. Springer, Berlin

Håkanson L, Gyllenhammar A (2005) Setting fish quotas based on holistic ecosystem modelling including environmental factors and foodweb interactions - a new approach. Aquat Ecol 39(3):325351. doi:10.1007/s10452-005-3418-x

Hansen AB, Lassen P (2008) Screening of phenolic substances in the Nordic environments. Nordic Council of Ministers. Tema Nord 530:145

Hansson M, Andersson L, Axe P (2011) Areal extent and volume of anoxia and hypoxia in the Baltic Sea, 1960-2011, REPORT OCEANOGRAPHY No. 42

Heinis LJ, Knuth ML, Liber K, Sheedy BR, Tunell RL, Ankley GT (1999) Persistence and distribution of 4-nonylphenol following repeated application to littoral enclosures. Environ Toxicol Chem 18: 363-375. doi:10.1002/etc.5620180302

HELCOM (2009) Reinforcing oil spill response capacity in the Baltic. Helsinki, Helsinki Commission

HELCOM (2010) Hazardous substances in the Baltic Sea—an integrated thematic assessment of hazardous substances in the Baltic Sea, Balt. Sea Environ. Proc. No. 120B

Isobe T, Nishiyama H, Nakashima A, Takada H (2001) Distribution and behaviour of nonylphenol, octylphenol, and nonylphenol monoethoxylate in Tokyo metropolitan area: their association with aquatic particles and sedimentary distributions. Environ Sci Technol 35:1041-1049. doi:10.1021/es001250i

Jahan K, Ordóñez R, Ramachandran R, Balzer S, Stern M (2008) Modeling biodegradation of nonylphenol. Water Air Soil Pollut: Focus 8:395-404. doi:10.1007/s11267-007-9148-4

Jobling S, Sumpter JP (1993) Detergent components in sewage effluent are weakly oestrogenic to fish: an in vitro study using rainbow trout (Oncorhynchus mykiss) hepatocytes. Aquat Toxicol 27(3):361-372

Jobling S, Sumpter JP, Sheahan D, Osborne JA, Matthiessen P (1996) Inhibition of testicular growth in rainbow trout (Oncorhynchus mykiss) exposed to estrogenic alkylphenolic chemicals. Environ Toxicol Chem 15(2):194-202

John DM, House WA, White GF (2000) Environmental fate of nonylphenol ethoxylates: differential adsorption of homologs to components of river sediment. Environ Toxicol Chem 19:293-300
Jonkers N, Laane R, De Voogt P (2003) Fate of nonylphenol ethoxylates and their metabolites in two Dutch estuaries: evidence of biodegradation in the field. Environ Sci Technol 37:321-327

Jonsson P (1992) Large-scale changes of contaminants in Baltic Sea sediments during the twentieth century, Dr Thesis. Uppsala Univ, Uppsala

Jonsson P (2000) Sediment burial of PCBs in the offshore Baltic Sea. AMBIO 29(4):260-267. doi:10.1579/0044-7447-29.4.260

Jonsson P, Carman R, Wulff F (1990) Laminated sediments in the Baltic: a tool for evaluating nutrient mass balances. Ambio 13:152-158

Khim JS, Kannan K, Villeneuve DL, Koh CH, Giesy JP (1999) Characterization and distribution of trace organic contaminants in sediment from Masan Bay, Korea. 1. Instrument analysis. Environ Sci Technol 33:4199-4205

Koniecko I, Staniszewska M, Falkowska L, Burska D, Kielczewska J, Jasinska A (2014) Alkylphenols in surface sediments of the Gulf of Gdansk (Baltic Sea). Water Air Soil Pollut 225:2040. doi:10.1007/ s11270-014-2040-8

Kramarska R (1995) Surficial bottom sediments. In: Dadlez, R Mojski, JE Słowańska B Uścinowicz S Zachowicz J (Eds.). Geological Atlas of Southern Baltic. Wydawnictwo Kartograficzne Polskiej Agencji Ekologicznej S.A, Sopot-Warszawa (in Polish)

Kumata H, Sanada Y, Takada H, Ueno T (2000) Historical trends of Ncyclohexyl-2-benzothiazolamine, 2-(4-morpholinyl) benzothiazole, and other anthropogenic contaminants in the urban reservoir sediment core. Environ Sci Technol 34(2):246-253

Kurihara R, Watanabe E, Ueda Y, Kakuno A, Fujii K, Shiraish F, Hashimoto S (2007) Estrogenic activity in sediments contaminated by nonylphenol in Tokyo Bay (Japan) evaluated by vitellogenin induction in male mummichogs (Fundulus heteroclitus). Mar Pollut Bull 54:1315-1320

Lara-Martin PA, Petrovic M, Gomez-Parra A, Barcelo D, Gonzales-Mazo (2006) Presence of surfactants and their degradation intermediates in sediment cores and grabs from the Cadiz Bay area. Env Pollut 144: 483-491

Lepper P (2005) Manual on the methodological framework used to derive environmental quality standards for priority substances of the Water Framework Directive (2000/60/EC). Fraunhofer-Institute Molecular Biology and Applied Ecology, Germany, p 47

Lewandowska A, Staniszewska M, Falkowska L, Witkowska A, Bełdowska M, Machuta M (2012) Mróz D (2012) Elemental and organic carbon, benzo(a)pirene and alkyl-phenols as a function of aerosol particle size in urbanized coastal zone of the Gulf of Gdansk. In: Konieczyński J (ed) OCHRONA POWIETRZA W TEORII I PRAKTYCE. IETU PAS, Zakopane, pp 14-16.10

Loos R, Locoro G, Comero S, Contini S, Schwesig D, Werres F, Balsaa P, Gans O, Weiss S, Blaha L, Bolchi M, Gawlik BM (2010) PanEuropean survey on the occurrence of selected polar organic persistent pollutants in ground water. Water Res 44:4115-4126

Mayer LM (1993) Organic matter at the sediment-water interface. In: Engel MN, Macko SA (eds) Organic geochemistry. Principles and Applications. Plenum Press, New York, pp 171-184

McLeese DW, Zitko V, Sergeant DB, Burridge L, Metcalfe CD (1981) Lethality and accumulation of alkylphenols in aquatic fauna. Chemosphere 10(7):723-730

Milinovič J, Lacorte S, Rigol A, Vidal M (2015) Sorption behaviour of nonylphenol and nonylphenolmonoethoxylate in soils. Chemosphere. doi:10.1016/j.chemosphere.2014.12.037

Nunez L, Turiel E, Tadeo JL (2007) Determination of nonylphenol and nonylphenolethoxylates in environmental solid samples by ultrasonic-assisted extraction and high performance liquid chromatography-fluorescence detection. J Chromatogr 1146:157163

OSPAR (2009) Background document on nonylphenol/ nonylphenolethoxylates. OSPAR Commision, London 
Petrovic M, Fernandez-Alba AR, Borrull F, Marce RM, Gonzalez ME, Barcelo D (2002) Occurrence and distribution of nonionic surfactants, their degradation products, and linear alkylbenzene sulfonates in coastal waters and sediments in Spain. Environ Toxicol Chem 21: $37-46$

Pojana G, Gomiero A, Jonkers N, Marcomini A (2007) Natural and synthetic endocrine disrupting compounds (EDCs) in water, sediment and biota of a coastal lagoon. Environ Int 33:929-936

Robbins JA (1978) Geochemical and geophysical applications of radioactive lead. In: Nriagu JO (ed) Biogeochemistry of lead in the environment. Elsevier, Amsterdam, pp 285-393

Schlenk D, Sapozhnikova Y, Irwin MA, Xie L, Hwang W, Reddy S, Brownawell BJ, Armstrong J, Kelly M, Montagne DE, Kolodziej EP, Sedlak D, Snyder S (2005) In vivo bioassayguided fractionation of marine sediment extracts from the Southern California Bight, USA, for estrogenic activity. Environ Toxicol Chem 24:2820-2826

Senthil Kumar K, Sajwan KS, Richardson JP, Kannan K (2008) Contamination profiles of heavy metals, organochlorine pesticides, polycyclic aromatic hydrocarbons and alkylphenols in sediment and oyster collected from marsh/estuarine Savannah GA, USA. Mar Pollut Bull 56:136-149

Soto AM, Justicia H, Wray JW, Sonnenschein C (1991) p-Nonyl-phenol: an estrogenic xenobiotic released from "modified" polystyrene. Environ Health Persp 92:167-173

Staniszewska M, Falkowska L, Grabowski P, Kwaśniak J, MudrakCegiołka S, Reindl AR, Sokołowski A, Szumiło E, Zgrundo A (2014) Bisphenol A, 4-tert- octylphenol, 4- nonylphenol in the Gulf of Gdansk (Southern Baltic). Arch Environ Con Tox 67(3): 335-347. doi:10.1007/s00244-014-0023-9

Staniszewska M, Koniecko I, Falkowska L, Krzymyk E (2015) Occurrence and distribution of bisphenol $\mathrm{A}$ and alkylphenols in the water of the gulf of Gdansk (Southern Baltic). Mar Pollut Bull 91(1):372-379. doi:10.1016/j.marpolbul.2014.11.027

Suplińska M, Pietrzak-Flis Z (2008) Sedimentation rates and dating of bottom sediments in the Southern Baltic Sea region. Nukleonika 53: 105-111

Szmytkiewicz A, Zalewska T (2014) Sediment deposition and accumulation rates determined by sediment trap and ${ }^{210} \mathrm{~Pb}$ isotope methods in the Outer Puck Bay (Baltic Sea). OCEANOLOGIA 56(1):85106. doi:10.5697/oc.56-1.085

UBA (2006) Data Sheet No. 24:Nonylphenol. Priority substances of the Water Framework Directive (in German)

Van Metre PC, Mahler BJ (2005) Trends in hydrophobic organic contaminants in urban and reference lake sediments across the United States, 1970-2001. Environ Sci Technol 39(15):5567-5574

Warzocha J (1995) classification and structure of macrofaunal communities in the southern Baltic. Arch Fish Mar Res 42(3):225-237

Wulff F, Rahm L, Larsson PA (2001) Systems analysis of the Baltic Sea ecological studies. Springer, Berlin

Ying GG, Williams B, Kookana R (2002) Environmental fate of alkylphenols and alkylphenolethoxylates - a review. Environ Int 28(3):215-226. doi:10.1016/S0160-4120(02)00017-X

Ying GG, Kookana RS, Dillon P (2003) Sorption and degradation of selected five endocrine disrupting chemicals in aquifer material. Water Res 37(15):3785-3791. doi:10.1016/S0043-1354(03)00261-6

Zalewska T, Woroń J, Danowska B, Suplińska M (2015) Temporal changes in $\mathrm{Hg}, \mathrm{Pb}, \mathrm{Cd}$ and $\mathrm{Zn}$ environmental concentrations in the southern Baltic Sea sediments dated with ${ }^{210} \mathrm{~Pb}$ method. Oceanologia 57:32-43

Zhou JL (2006) Sorption and remobilization behavior of 4-tertoctylphenol in aquatic systems. Environ Sci Technol 40(7):22252234. doi:10.1021/es052002v 